\title{
Estereotomía: teoría y práctica, justificación y alarde
}

\author{
Stereotomy: theory and practice, justification \\ and whimsicality
}

$\underline{\text { E. Rabasa }}^{(*)}$

\section{RESUMEN}

En el desarrollo histórico de la construcción en piedra tallada convergen las estrategias de la construcción, los problemas del despiece de los aparejos, las técnicas de la labra de la piedra, y los trazados y sistemas de representación. En este artículo se comentará esta evolución y se mostrará cómo la realidad de la relación de los cortes de piedra con conceptos abstractos como la geometría, la estabilidad o el dibujo, es algo diferente a lo que el profano puede imaginar. Se analizará lo natural o forzado de la relación de la teoría con la práctica de esta materia, y la utilidad de algunos esfuerzos, que se revelan más dirigidos al alarde o la voluntad de realizar un capricho.

\section{SUMMARY}

Construction strategies, problems of arrangement, stonecutting techniques and tracings as well as representation systems converge in the historical development of the carved stonework. This article will discuss these developments and show the reality of the relationship between Stereotomy or stonecutting and such abstract concepts as geometry, stability and drawing, which might be different from what the layman could imagine. It will analyze the natural or forced connection between theory and practice in this matter, and also the usefulness of certain efforts, which are otherwise performed just to show off or be meant as a whimsicality.
Palabras clave: Estereotomía; cantería; historia de la construcción; capricho; aparejo.
Keywords: Stereotomy; stonecutting; construction history; whimsicality; quartering. 
Una de las primeras tareas a las que se puede enfrentar la investigación reciente sobre la historia de los cortes de piedras es la desmitificación del objeto de estudio. El término más común para hablar de estos temas es "estereotomía", palabra culta que casi todo el interesado asocia fácilmente con los aparejos, más o menos geométricamente complejos, de piedra tallada. A partir de ahí, es posible que la imaginación se vea tentada de hacerse una idea siguiendo algunos supuestos generales muy extendidos. Así, muchas veces se espera que la estereotomía sea una ciencia, o al menos una técnica derivada de la ciencia geométrica; que, en consecuencia, depende de lo avanzado de los conocimientos geométricos y es su aplicación; que busca siempre la resolución sencilla y económica de los problemas que la actividad constructiva encuentra; que será naturalmente mejor un texto de estereotomía del siglo XIX que uno del siglo XVII; que el propio término estereotomía es griego y por tanto antiguo; que comprende conocimientos estrechamente ligados a la mecánica, etc. De todo esto se puede decir que nada es cierto, incluso que, desde algún punto de vista, todo es casi al contrario.

\section{LABRA Y PREVISIÓN}

Las operaciones de labra son aplicadas sucesivamente sobre la piedra, y sucede muy a menudo que un determinado paso requiere establecer previamente referencias, por ejemplo directrices para apoyar una regla, con objeto de comprobar la ejecución de un plano o una superficie reglada. Incluso tallando directa y sucesivamente las caras de la pieza, puede ocurrir que, para definir alguna, convenga labrar una superficie mayor de la necesaria y limitarla después, quizá con una plantilla. Si se parte de una escuadría previa, capaz de contener a la dovela, sobre la que dibujar las proyecciones, es evidente que se va a perder una gran parte del trabajo inicial. En consecuencia siempre hay un trabajo preparatorio, y suele ocurrir que las referencias que contiene se encuentran en una parte del material que debe desaparecer. Es decir, es muy habitual que el proceso pase por fases y trabajos de labra provisionales. La práctica muestra que es conveniente no continuar con un nuevo paso hasta que los anteriores están correctamente terminados. ${ }^{1}$ Así pues, la previsión de las operaciones a realizar, que es condición indispensable para la eficacia y división del trabajo, además no resulta ajena a los hábitos del cantero.

Esta es la clave que liga los métodos artesanales con el desarrollo de los trazados geométricos, la previsión, la anticipación
When studying the history of stone-cutting it is important to challenge first some of the misconceptions that surround the term "stereotomy", a cult-word that refers to the theory of stonecutting, and the preconceived ideas that come with it.

There are some examples:

First of all, Stereotomy is thought to be pertaining to, or at least a technique, derived from the geometrical science and consequently its quality should depend on the state-of-the-art of the geometrical knowledge at a given point in time.

Following that course of thinking one could consider that the texts on Stereotomy of the 19th century are better than those written in earlier centuries. It is also often believed that Stereotomy is always aiming to simple and inexpensive solutions.

Moreover, as the word "stereotomy" is of Greek origin, the tendency is to regard the subject as born in antique times, or perhaps that Stereotomy is strongly linked to Mechanics, and so on.

However, none of these ideas are actually true, furthermore from some point of view, it all could be exactly the opposite.

\section{CARVING AND PLANNING THE ACTION}

When stone is carved, the diverse operations follow an order and it is often necessary to establish references to continue to the next step. For example, you may need to set guidelines to support a ruler in order to check the carving of a plan or a ruled surface. Sometimes faces are carved in successive order on the piece. So it often happens that carving of facets involves working on an area larger than what it is strictly necessary, and then limiting it by drawing its outline with the help of a template. Other times it starts with a previous squaring, able to hold the piece, and its projections are then plotted to subtract the stone left. It is therefore always necessary to establish references in a part of the material which will then disappear. Consequently there is a lot of temporary work. In addition, stonemasons usually recommend not continuing with a new step until the previous one is completely finished. For an effective construction process it is necessary to establish a division of labor and that requires careful planning of the series of operations to be performed. ${ }^{1}$ As we have seen above, the anticipation of actions to carry out is included in stonemason's work.

The manual activity of the artisan as well as the representation modes are guided by a preparatory planning. 
de la forma de las piezas mediante un dibujo.

Sintéticamente, se puede decir que la cantería medieval consigue organizar un sistema, para el diseño de las bóvedas nervadas, que pasa por el trazado esquemático de las líneas directrices de los nervios, y que este trazado, junto con los perfiles de los nervios, es guía suficiente para el proceso completo. A partir del siglo XVI, Ilegando a Francia y España las nuevas formas renacentistas, hay aquí un empeño en construirlas en piedra tallada, lo que inicia un esfuerzo por resolver gráficamente problemas complejos, esfuerzo que ocupará a la disciplina hasta el siglo XVIII. A final del siglo XVIII Gaspard Monge creará la Ilamada Geometría Descriptiva como organización racional y abstracta de los procedimientos gráficos propios del corte de piedras.

\section{CONCEPCIÓN GENERAL Y SISTEMAS CONSTRUCTIVOS}

Examinemos la relación entre los métodos de labra de las piezas y los sistemas constructivos generales. ${ }^{2}$ Lo más sobresaliente del sistema gótico de construcción de bóvedas es que tanto la forma general como los elementos y sus partes responden al diseño realizado conforme a algunos principios elementales. ${ }^{3}$ En las bóvedas de terceletes o más complejas, lo primero, que será guía del diseño y apoyo material de la construcción, es la planta esquemática de la nervadura. Los nervios presentan perfiles verticales, y se cruzan en los nudos de la red, las claves, que suelen presentar también una organización vertical (Figura 1). En el enjarje, inicio de la bóveda en el que los lechos son horizontales, los nervios están mezclados e interpenetrados. La talla de ambos elementos es eficazmente controlada. ${ }^{4}$

En efecto. En ambos lugares, enjarjes y claves, ese control se efectúa mediante trazados en los planos horizontales de las piezas. Estos planos son los lechos, en el caso del enjarje, y un plano que Robert Willis (4) Ilamó "superficie de operación" en el caso de las claves. Alejamientos con respecto al eje o inclinaciones con respecto a la vertical son controlados por el cantero con referencia a esos planos horizontales, y quizá en alguna ocasión otros planos sean referencias relevantes. En consecuencia, no podemos decir que el procedimiento sea literalmente el Ilamado "de escuadría" (a partir de las proyecciones ortogonales sobre las caras de un sólido capaz), pero sí hay cierta similaridad, y se advierte el protagonismo de la planta o proyección horizontal.
Mediaeval stonework managed to organize a system for designing ribbed vaults, which requires the schematic layout of the guidelines of the ribs. This simple layout, with its profiles of ribs, was all the mason needed to follow. Bricks were used in Italy to construct Renaissance vaults, but Spain and France reached these new forms by using carved stone instead. This led to the effort of solving the complex problems that came along with this new technique, an effort that existed until the end of 18th century, when the Frenchman Gaspard Monge created Descriptive geometry, which is a rational organization of graphic procedures for stonecutting.

\section{GENERAL DESIGN AND CONSTRUCTION SYSTEMS}

Let us examine the relationship between general building systems and carving methods. ${ }^{2}$ In the case of the Gothic system, both general layout and pieces design follow some basic principles. ${ }^{3}$ To design tierceron vaults or more complex Gothic vaults, a schematic plan of the ribs guides both the design and the material construction. The profiles of the ribs are vertical and intersect at the nodes of the grid, where keystones are placed, having a vertical layout too (Figure 1). The beginning of the vault is the tas-de-charge. In this place there are horizontal beds, and ribs are mixed together. Carving of both keystones and tas-de-charge is effectively controlled. ${ }^{4}$

In both places, keystones and tas-de-charge, the control is made by drawing the layout on the horizontal planes of the pieces. These planes are beds, in the case of tas-decharge, and a top horizontal plane called "operating surface" by Robert Willis (4), in the case of the keystones. Distances from the axis or inclinations are controlled by the mason with references to these horizontal planes. This is not strictly the procedure called "equarrissement" (from the orthogonal projections on the faces of a solid able to contain the piece), but it is similar. The role of plan or horizontal projection is particularly important in these cases.
2 Dejando claro que los límites son difusos, tanto históricamente como en cada intervención real, se ha dicho (1) que, en principio, para la formalización de las piezas individuales, la cantería gótica procede por escuadría (a partir de proyecciones sobre un sólido capaz) y la renacentista por plantillas (directamente, cara po cara). Para completar el panorama, la antigua modela con talla in situ.

2 The boundaries are vague, both historically and in each individual case. It has been stated (1) that, in principle, to formalize the individual pieces, Gothic stonework proceeds by squaring (projections from a capable solid) and the Renaissance one by templates (directly, face by face). To complete the idea, the older models were carved in situ.

3 El término "principio" en la obra de Viollet-le-Duc y Choisy es interesante; estos autores lo emplean para aludir a las ideas elementales sobre procedimientos materiales.

3 The term "principle" in the work by Viollet-le-Duc and Choisy is interesting; these authors use it to refer to elementary ideas on material procedures.

${ }^{4}$ Véase (2). Para la variedad de bóvedas resultantes, véase (3).

${ }^{4}$ See (2). On the variety of resulting vaults, see (3). 
1. Bóveda de crucería en el manuscrito de Hernán Ruiz (155860)

1. Rib vault in the manuscript by Hernán Ruiz (1588-60)
${ }^{5}$ En alguna ocasión incluso interviene materialmente en el proceso, pues, como ocurre con la bóveda gótica, se dibuja bajo el aparejo para controlar, con el "plomo", la situación de los elementos. Sin embargo, en una bóveda renacentista la cimbra suele representar un estorbo para el control del aparejo por la planta. Véase (5, pp.276-277).

${ }^{5}$ Occasionally it is even physically involved in the process. For instance, in the Gothic vault, it is drawn under the arch or vault to control, with the "plumb", the location of the items. However, in a Renaissance vault formwork often obstructs the process to control the work by the plan. See (5, pp.276-277).

${ }^{6}$ La sección arquitectónica, tal como la conocemos, es decir, con proyección ortogonal de los elementos no frontales de un espacio interior, no aparece correctamente hasta los dibujos de Antonio de Sangallo (6).

6 The architectural section, as we know, i.e. orthogonal projection of non front elements of an interior space, does not appear correctly before the drawings of Antonio da Sangallo (6).

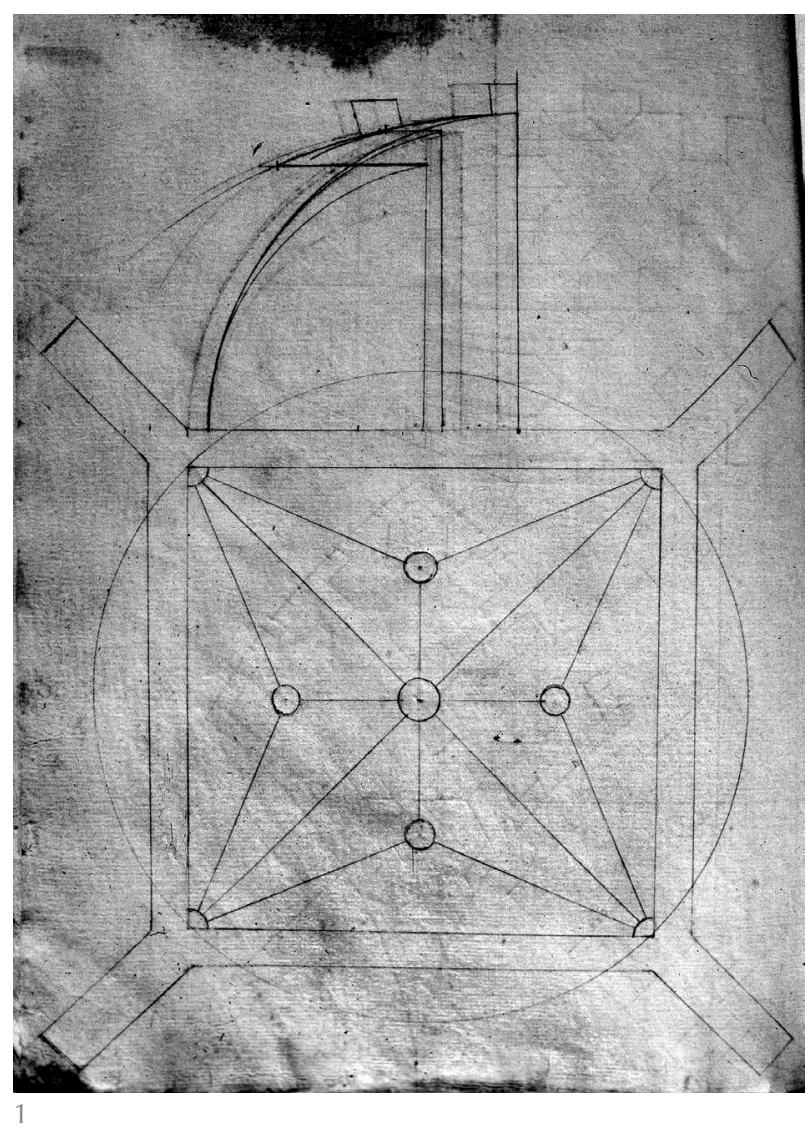

También es cierto que la planta seguirá siendo la proyección privilegiada en la tratadística renacentista. ${ }^{5}$ Las monteas ofrecen siempre la planta, y no siempre un alzado tal como lo entendemos ahora, aunque sí abatimientos de elementos situados en diversos planos verticales. La gravedad ha hecho siempre que sea evidente la proyección horizontal, pero la proyección del volumen sobre un plano vertical, que el sistema de Monge nos ha ofrecido como simétrica y correspondiente con la horizontal, es una abstracción prácticamente inexistente hasta el siglo XVI. ${ }^{6}$

El procedimiento de escuadría no dejará de ser empleado hasta el final de la historia de la estereotomía, si bien los tratados elogian continuamente a quien es capaz de evitarlo (de evitar el trabajo previo de talla de una escuadría), procediendo directamente a la talla sucesiva de las caras de la pieza definitiva.

\section{APORTACIÓN DE LA CIENCIA GEOMÉTRICA}

Estos métodos exigen un esfuerzo de imaginación espacial que nada tiene que ver con la deducción lógica de un tratado de geometría. Tendemos a pensar que el dominio de la geometría culta es base para las operaciones espaciales. Si sus textos fundacionales, especialmente los Elementos de Euclides, gozaron de prestigio, no es ex-
The plan will also be the main projection in Renaissance treatises on stonecutting. ${ }^{5}$ Full size layouts always contain a plan and usually rabattements of vertical elements, but elevations as understood nowadays are not always found. The horizontal projection is easy to be understood because of the vertical direction of gravity. But projecting onto a vertical plane with arbitrary horizontal projection direction, which Monge's system presents as equivalent to the plan, is an abstraction almost nonexistent until the 16th century. ${ }^{6}$

The process of squaring will be used until the end of the history of stereotomy. But treatises praise people able to avoid it and directly undertake the successive carving of the faces of the final piece.

\section{CONTRIBUTION OF GEOMETRY}

These methods demand an effort on space imagination that has nothing to do with the logical deduction of a treatise on Geometry. Usually we think that the domain of highbrow geometry is important for the conception of spatial operations. Euclid's work Elements enjoyed a lot of prestige, and because of that it was mentioned in stonework treatises, but it gives nothing but an abstract justification of theoretical propositions. Its contents do not promote the skill of imagination or the procedures to solve practical problems. This is not useful 
traño que también los tratadistas que escribieron libros de cortes de piedras invoquen a Euclides o comiencen mencionándolo. Pero la realidad es que lo esencial de los Elementos no es la habilidad imaginativa ni la información sobre procedimientos de resolución de problemas, sino la justificación abstracta de enunciados. Esto no es útil al cantero, y la necesidad de una base distinta es evidente, por ejemplo, en el libro de Philibert De l'Orme, como comentaremos más adelante. $^{7}$

Es posible que en algún caso la cantería tomara prestada de otras áreas la concepción de un procedimiento a seguir para obtener las formas. Por ejemplo, tras el descubrimiento de América, la actividad cartográfica y las realizaciones canteriles de bóvedas semiesféricas, recurrieron a ideas semejantes en relación con los desarrollos aproximados de las esferas (8). Pero, de haber una relación, serían intuiciones y procedimientos prácticos, y no demostraciones y deducciones, lo que se transfiriera hacia la teoría de los cortes de piedras. El tratado de Frézier (9) comienza dedicando un tomo a la explicación de conceptos geométricos; para esto hay que esperar a 1737 . Esta adición de Frézier es un buen apoyo para la concepción abstracta de las operaciones, aunque, como consecuencia, en la parte dedicada a la estereotomía propiamente dicha, el autor complica a veces innecesariamente los trazados.

Desde el punto de vista de un científico del siglo XIX, lo más distintivo de la estereotomía sería el empleo de métodos gráficos de resolución de problemas espaciales, pero eso no fue tomado de la ciencia. Al contrario, esta habilidad operativa y gráfica práctica se incorporará a la geometría; lo hará plenamente cuando Monge ordene y sistematice los procedimientos artesanales en su Geometría Descriptiva. Así pues, históricamente es posible decir que la geometría debe más a los canteros que lo que éstos deben a la geometría. Aunque exagerando en una defensa del oficio, algo hay de cierto en las palabras del compagnon Agricole Perdiguer (10), "Las más hermosas catedrales estaban ya en pie cuando Monge y Desargues vinieron a decirnos, a nosotros, los artífices, qué hay que hacer para tallar la piedra y la madera." 8

En el ámbito de las bóvedas góticas es evidente que, en ocasiones, se buscaba la complejidad del resultado, pero también que los procedimientos son sistemáticos y eficaces. El Renacimiento invierte la situación, construyendo una traza de cantería capaz de resolver cada forma propuesta por la arquitectura clásica. for the stonemason and the needing of a different base is evident, for instance, in the book by Philibert De l'Orme, as it will be discussed later. ${ }^{7}$

Perhaps some procedures were taken from other areas. After America's discovery, for instance, cartography and stonecutting for hemispherical domes used similar ideas related to approximated spheres developments (8). But if a knowledge transfer actually existed, it would be a transmission of practical procedures and iniuitions, no demonstrations nor deductions. Frézier's treatise (9) begins with a volume devoted to explaining geometrical concepts; it is in 1737 when this happens for the first time. This previous explanation by Frézier is a good base of support for the abstract conception of the operations, although sometimes, as a consequence, the author needlessly complicates the layouts in the part devoted to stereotomy.

Using graphical methods to solve spatial problems would be the most significant feature of Stereotomy for the 19th century authors. But that ability was not taken from the science of geometry. On the contrary, it is a practical graphical skill which became a part of Geometry, especially when Gaspard Monge wrote his Descriptive Geometry. So, we can say that historically Geometry owes more to stonemasons rather than the other way round. The leader compagnon Agricole Perdiguer (10) wrote: "The most beautiful cathedrals were already standing when Monge and Desargues came to tell us, the workers, how to do to the carving of stone and wood. ${ }^{8}$

Regarding Gothic vaults, it is obvious that sometimes complexity was expressly sought, but it is also true that systematic and effective procedures were employed. On the other hand, a theory able to resolve problems via the classic architectural forms was elaborated in the Renaissance.

This discipline was called "traza" (tracing, "trait" in French), "cortes" (cuts), or sometimes just "arte de la traza" (art of tracing), as it was the most important thing that could be solved with tracing. It was also called "montea", and in the 18th century the term "stereotomy" became current to give it a scientific name. This word has Greek roots, but it was invented merging the term stereo, which is solid, and tomos, which is cut, after a famous dispute at the end of the 17th century (12, p.98).

Treatises will still be sometimes called "de cortes de piedras" during the 19th century, but the term mainly used will
7 Incluso en esta función, explicativa de propiedades geométricas, los procedimientos de Euclides fueron discutidos por Shopenhauer $(7, \S 15)$, quien defendía un acceso intuitivo a la demostración.

${ }^{7}$ Even in this role, as explanation of geometrical problems, Euclid procedures were discussed by Schopenhauer $(7, \S 15)$, who defended intuitive access to the geometrical knowledge.

${ }^{8}$ Es curioso, en este sentido, que en alguna ocasión se haya recurrido a la comprobación gráfica (que es como decir material) de una propiedad geométrica para asegurar el camino del conocimiento. Es lo que José Calvo llama geometría empírica (11).

${ }^{8}$ It is curious that graphical verification of geometrical properties has been occasionally used to ensure the knowledge. This is what José Calvo called empirical geometry (11). 
La disciplina recibía diversas denominaciones, "traza", "cortes", a veces simplemente el "arte de la traza", pues era la traza por antonomasia, "montea" más adelante, pero en el siglo XVIII empieza a ser usado el término "estereotomía", con la intención de dignificarla con un nombre científico. Estereotomía tiene, evidentemente, raíces griegas, pero es un neologismo, una composición de estereo, sólido y tomos, cortar, que no existe antes de ser usada en una célebre disputa a finales del siglo XVII (12, p.98).

En el siglo XIX los tratados serán Ilamados aún a veces "de cortes de piedras", pero casi siempre "de estereotomía". Al contrario de lo que ocurrió en los tres siglos anteriores, esta literatura del XIX ya no se limita a España y Francia, lugares cuna de la teoría y la práctica de los modernos cortes de piedra. Se extiende la tratadística por toda Europa, y los autores son ahora en su mayoría geómetras, o técnicos especializados en la docencia de la geometría -sin embargo, los tratados no van a ofrecer algo muy distinto a lo que encontramos en siglos anteriores, una serie de aparejos para los que se proponen procedimientos de trazado, con poca sistematización más allá de la agrupación por familias-.

Estos procedimientos, lógicamente, también suelen buscar la facilidad y la economía. Pero no siempre. Y cuando hay complicaciones innecesarias, a veces es evidente que no se espera el asombro por parte del espectador lego, sino que un raro despiece está dirigido a llamar la atención del entendido. Así ocurre en algunos casos que vamos a comentar.

\section{BÓVEDAS ESFÉRICAS}

Conviene primero recordar que las bóvedas semiesféricas o vaídas se suelen despiezar en dovelas organizadas en hiladas horizontales. Las juntas aparentes del intradós son paralelos y meridianos. Entre las hiladas hay lechos troncocónicos (siguiendo los paralelos) y entre las dovelas hay juntas verticales planas (siguiendo los meridianos). Todas estas superficies ocultas encuentran perpendicularmente al intradós. Sin entrar en el particular modo de talla de estas piezas, que es del tipo que llamamos directo, bastará decir que todas las piezas de cada hilada son iguales, o bien más o menos largas, y que su talla requiere una plantilla para la cara de intradós. Cada hilada se puede asimilar a un tronco de cono, fácilmente desarrollable, y el pequeño tamaño, en comparación con el conjunto, de una cara de intradós permite emplear una plantilla plana para marcar los límites de esa cara. Conservamos alguna montea, y be "de estereotomía". The books at that time are published not only in Spain and France as it had happened in the three previous centuries. Authors are now mainly geometers or technicians specialized in geometry teaching. However, texts will not show something different from before, a little systematic collection of examples with tracing proposals.

Procedures described in stereotomy treatises often seek also simplicity and economy, but not always. When there are unnecessary complications, it is sometimes evident that they are thought not to amaze a layman but to call the attention of those skilled in the art. Let's see some cases.

\section{SPHERICAL DOMES}

Quartering hemispherical domes or sail vaults usually consists of voussoirs arranged in horizontal rows. The visible joints of the intrados follow the parallels and meridians of the sphere. Beds between rows are conical (following parallels), and joints between pieces in the same row are vertical planes (following meridians). All these hidden surfaces meet the intrados orthogonally. All voussoirs at the same row are equal, just more or less longer, and its carving demands the use of an intrados face template. The intrados face of each row is similar to a truncated cone, easy to be developed, and its small size -comparing with the whole- lets using a flat template to mark the face limits. Evidences of these developments of truncated cones may be seen in some preserved true size layouts and treatises drawings (Figure 2). ${ }^{9}$

Sail vaults were also arranged by rows following vertical arcs, that is, with voussoirs rotating around horizontal axes. Let us remark that pieces are equal to the fist mentioned quartering, just with a different spatial position. This arrangement is called "por hiladas cuadradas" (by squared rows), and they may be parallel to the perimeter or to the diagonals of the plan (Figure 3). ${ }^{10}$ There are a lot of Renaissance vaults following these patterns. Even in the 18th century we can find an evidence of this axis change playing in the niches of the courtyard of the Lonja de Barcelona, with a different vault of these types in each of four corners (Figure 4). This case is actually a caprice.

Professor Ana López Mozo studied sail vaults by squared rows. Some of them, but especially the one at the original convent kitchen in the Escorial (16), show slight irregularities, difficult to be appreciated at first sight, in order to fit local conditions. If 
muchos dibujos en tratados, que muestran los desarrollos de troncos de cono necesarios para la obtención de esas plantillas (Figura 2). ${ }^{9}$

Se construyeron también bóvedas vaídas mediante hiladas de dovelas verticales, es decir, que giran alrededor de ejes horizontales. Con este aparejo, en el que las piezas sólo cambian de posición espacial, se pueden componer despieces "por hiladas cuadradas", e incluso girar estas hiladas cuarenta y cinco grados, para mayor rareza (Figura 3). ${ }^{10}$ Así hicieron los canteros renacentistas. Incluso en el siglo XVIII podemos encontrar una ilustración del juego de cambios de eje que esto supone, en las hornacinas del patio de la Lonja de Barcelona, una en cada rincón y las cuatro diferentes (Figura 4). Es fácil pensar que se trata de caprichos, y en este último caso es efectivamente así.
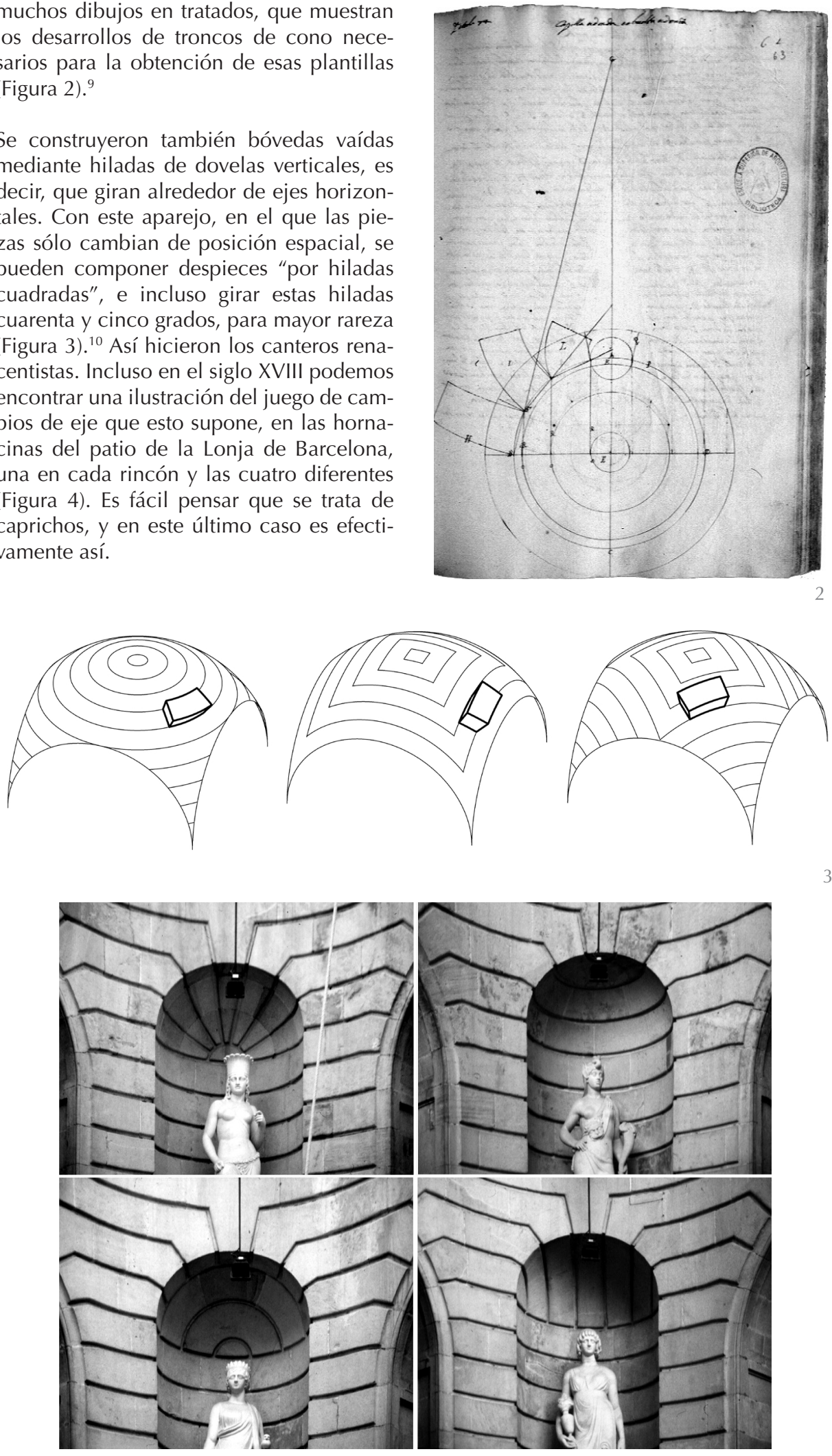

La profesora Ana López Mozo ha estudiado bóvedas de este tipo, vaídas por hiladas cuadradas. Varias de ellas, pero muy singularmente la de la cocina del monasterio de El Escorial (16), presentan ligeras irregularidades, no perceptibles a simple vista, para a quartering by "hiladas redondas" (round rows) would have been used instead of "hiladas cuadradas", the construction would have been more complex and irregularities would have been more evident. In other words, horizontal circles tend to show
2. Traza para una bóveda de media naranja en el manuscrito de Alonso de Vandelvira (ca. 1575).

2. Tracing for a hemispherical dome in the manuscript by Alonso de Vandelvira (ca. 1575).

3. Bóvedas vaídas, por hiladas redondas horizontales, y dos variantes de hiladas cuadradas verticales.

3. Sail vaults, with round rows, and two versions with vertical squared rows.

4. Hornacinas en los cuatro rincones de la Lonja de Barcelona.

4. Niches at the four corners of the courtyard of the Lonja de Barcelona. ${ }^{9}$ Hay una montea de ese tipo en la
catedral de Sevilla (13, pp.334-341)
y en la iglesia parroquial de Carnota,
La Coruña (14). Es de suponer que las
que aparecen en los tratados repro-
duzcan, con menos hiladas, lo que se
hacía realmente.

${ }^{9}$ There is a layout of this type in the cathedral of Seville (13, pp.334-341) and in the Carnota parish church in La Coruña (14). It may be supposed that those in the treatises reproduce, with less courses, what was actually made.

${ }^{10}$ José Carlos Palacios explica estas variantes en su libro sobre el manuscrito de Alonso de Vandelvira (15).

${ }^{10}$ José Carlos Palacios explains these variations in his book on Vandelvira's manuscript (15). 
adaptarse a las condiciones de contorno. Del análisis de estos ejemplos se hace evidente que el empleo de "hiladas redondas" hubiera complicado la construcción y hubiera hecho muy aparentes las irregularidades. En concreto, los círculos de las hiladas delatarían a la vista defectos de forma que con las hiladas cuadradas no se advierten. Si se trata de una bóveda rectangular, las hiladas cuadradas evitan, además, el difícil encuentro de hiladas redondas con los arcos perimetrales.

Probablemente el despiece de una bóveda vaída por hiladas cuadradas simplifica la cimbra, y reduce el problema del abovedamiento a la construcción de una serie de arcos. Como señala Ana López Mozo (17), una de las más antiguas, romanas, con independencia de su modo de talla, es de este tipo, lo que conduce a pensar que no es una innovación caprichosa. Por otra parte, en el mundo bizantino se empleó desde el primer momento una disposición semejante para las bóvedas vaídas de ladrillo. Desde que Choisy estudiara el tema, todos han aceptado que las hiladas cuadradas de ladrillo fueron desarrolladas porque presentaban ventajas evidentes. También en la construcción bizantina es habitual el giro de los aparejos para acortar la luz que deben salvar las hiladas, lo que nos hace pensar en la disposición de hiladas cuadradas giradas de Vandelvira (la tercera en la Figura 3).

\section{BÓVEDA DE UNA SOLA HILADA HELICOIDAL}

Hay un paso más en la alteración del modelo convencional de hiladas redondas alrededor de un eje vertical. Se trata de la bóveda semiesférica de una sola hilada helicoidal, que, como la monda de una naranja, recorre la superficie hasta el polo. Este tipo de bóveda ha sido mostrada en el tratado de Philibert de l'Orme, de quien copian una larga serie de autores, reproduciendo el mismo dibujo, y los mismos errores. También aparece en el manuscrito de Alonso de Vandelvira, éste sin errores graves, si bien de él no lo toman otros (Figura 5). En cualquier caso, es un aparejo que, con respecto al modelo de hiladas redondas, presenta la singularidad de estar compuesto por piezas que son todas diferentes. $Y$ cada una de estas dovelas requiere una plantilla distinta, que no es fácil trazar. A pesar de esto, hemos podido encontrar hasta ahora seis realizaciones de este tipo de bóveda en España: una en la catedral de Murcia, de comienzos del XVI, dos atribuibles a Rodrigo Gil de Hontañón (en el palacio de los Guzmanes de León y en la catedral de Plasencia, en este caso sobre una escalera que horada un contrafuerte), otras tam- visible irregularities to a far greater extent than "hiladas cuadradas" would normally do. If it is a rectangular vault, the "hiladas cuadradas" avoid also the difficult union between round rows and boundary arches.

Choosing a quartering by "hiladas cuadradas" for a sail vault probably simplifies formwork and also construction, which becomes a problem of raising a series of arches. As it was noted by Ana López Mozo (17), one of the earliest known examples -setting aside the way for being carvedwas already of this type, which suggests that it was not a whimsical innovation. On the other hand, a similar arrangement was used in Byzantium from the very beginning to build brick sail vaults. It has been fully accepted after Choisy's studies on the topic that brick square rows were carried out because of presenting evident advantages. Rotating a square bonding to reduce the span of the rows is also a common practice in Byzantine construction, regarding the rotated square arrangement explained by Vandelvira (third in Figure 3).

\section{DOME OF A SINGLE HELICOIDAL ROW}

There is another type deriving from the hemispherical dome "por hiladas redondas" around a vertical axis: the dome with a single helicoidal row, which, as an orange peel, runs over the surface to the pole. It appears in the treatise by Philbert de l'Orme and was then copied by a large set of authors, all repeating the same quite serious mistakes. It is also shown in Vandelvira's manuscript, without important mistakes, but having no diffusion (Figure 5). By contrast with the model by "hiladas redondas", all voussoirs are different in this case. Each piece requires a different template, difficult to be drawn. Despite this, we have been able to find six vaults of this type in Spain so far: one in the Cathedral of Murcia, from the early 16th century, two ones attributable to Rodrigo Gil de Hontañón (at the palace of Guzmanes in Leon and at Plasencia Cathedral over a spiral staircase that pierces a buttress), and others from the 16th century in Medina Sidonia, Jerez de la Frontera and Talavera (Figure 6). ${ }^{11}$ As far as we know, there are no examples in France in spite of the spread of the book by De L'Orme: a possible exception could be a set of very flat much later vaults under the organ of St. Sulpice in Paris, where it is not really clear whether the pieces sustain or otherwise are suspended. ${ }^{12}$

It is hard to find a practical justification for this curious helicoidal quartering. The smaller dome of the ones mentioned 
bién del XVI en Medina Sidonia, Jerez de la Frontera, y Talavera (Figura 6). ${ }^{11}$ No hay, por lo que sabemos, ninguna en Francia, a pesar de la difusión del libro de De l'Orme, con la posible excepción de unas bóvedas planas muy posteriores que sostienen el órgano de San Sulpice de París, cuyas piezas no sabemos realmente si sostienen o están colgadas. ${ }^{12}$

Es difícil encontrar en este caso alguna justificación práctica para el curioso despiece helicoidal. La más pequeña de las citadas, siguiendo las instrucciones de los tratados, requeriría la elaboración de sesenta plantillas diferentes. A esto se añade que los above would require making sixty different templates. It is also important to consider that these examples are usually located in hidden places, so they could only be appreciated by well informed people.

However, comparison with brick construction may again show similar solutions. When bricks are set following round courses it is an advantage for organizing the simultaneous work of several people arranging each row following a different helix, as they will endless overlap. Thus transfer of procedures between techniques comes to be added to the tension between practice and whimsicality.

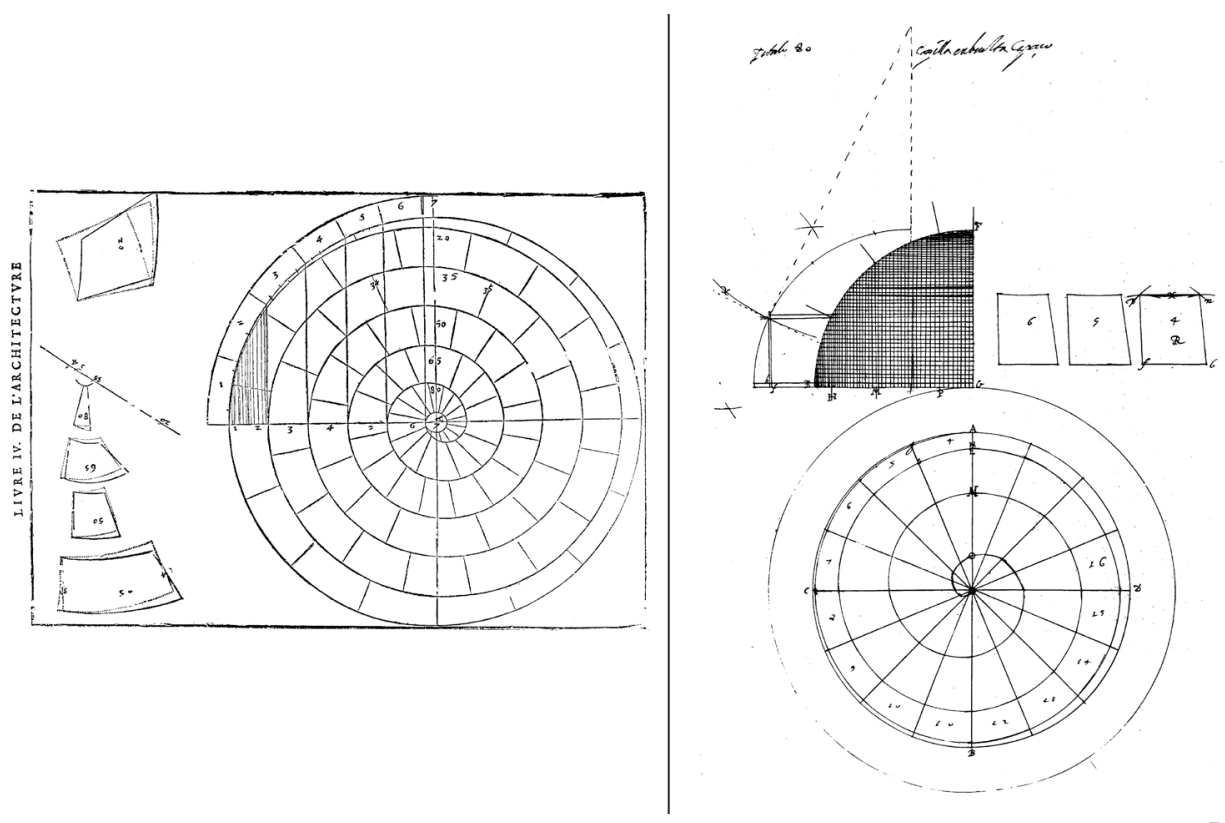

lugares en que están situados los ejemplos reales son algo escondidos, de manera que el alarde puede ser apreciado sólo por los bien informados.

Sin embargo, otra vez el ladrillo puede mostrarnos soluciones semejantes. Cuando se disponen los ladrillos por hiladas redondas, para el trabajo simultáneo de varios obreros, es ventajoso que cada línea de ladrillos siga una ligera hélice, de manera que las hiladas se superpongan y no tengan fin. Así pues, a la tensión entre lo caprichoso y lo práctico se superpone la transferencia de procedimientos entre técnicas.

\section{BÓVEDAS SOBRE PLANTA OVAL O ELÍPTICA}

Examinemos ahora un tipo de bóveda emparentada con la de media naranja. Si la base de la bóveda no es un círculo (o un cuadrado redondeado con pechinas) sino una figura oval (o perlongada con pechinas), toda la bóveda puede transformarse

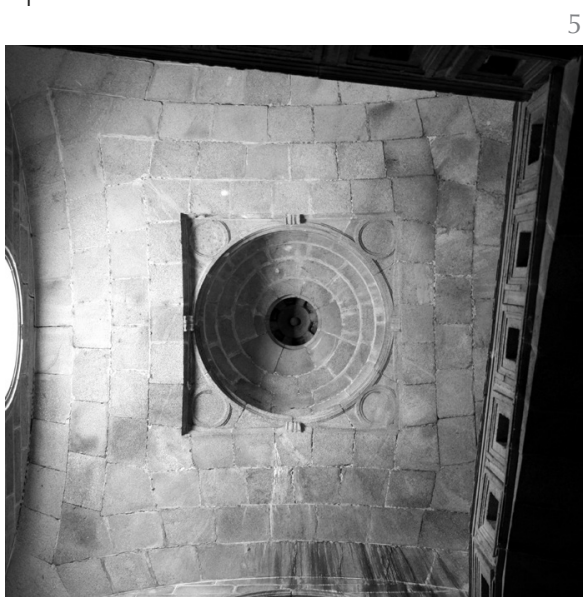

\section{VAULTS OVER AN OVAL OR ELLIPTICAL PLAN}

There is another type of vault directly related to the conventional hemispherical dome. If the base of the dome is not a circle (or a rounded square with pendentives) but an oval or elliptical figure, the entire vault can be extended to match it. The circles then
5. Bóveda en forma de "coquille de Limaçon" en el tratado de De l'Orme (izquierda), y "en vuelta de capazo" en el de Vandelvira (derecha).

5. Dome shaped like a "coquille de Limaçon" en the treatise by De l'Orme (left), and "en vuelta de capazo" in Vandelvira's (right).

6. Bóveda de una sola hilada helicoidal, sobre una bóveda vaída por hiladas cuadradas, en la escalera del monasterio de Santa Catalina en Talavera de la Reina (Toledo)

6. Dome of a single helicoidal row over a sail vault with squared rows, in the staircase of Santa Catalina monastery in Talavera de la Reina (Toledo).
11 En el paso a la sacristía de la iglesia de Medina Sidonia, San Juan de los Caballeros de Jerez, y el convento de Santa Catalina de Talavera.

11 In the passage to the sacristy of the church of Medina Sidonia, San Juan de los Caballeros de Jerez, and the convent of Santa Catalina de Talavera.

12 Hay también bóvedas de este tipo en la Anatolia del siglo XIII.

12 There are also vaults of this type from the 13th century in Anatolia. 
Bóveda de la sala capitular de la catedral de Sevilla; despiece según paralelos y meridianos.

7. Vault over the Chapter House in Seville Cathedral; arrangement by parallels and meridians.
${ }^{13}$ La diferencia entre un óvalo y una elipse de la misma proporción puede ser menor que la deformación de la bóveda. Como consecuencia, es posible discutir sobre si la base de una bóveda es oval o elíptica. La cuestión nominal también es resbaladiza: incluso aunque el tracista no sepa lo que es una elipse, puede emplear, deliberadamente, es decir, con conocimiento de las consecuencias de su elección, una curva que obtiene uniendo puntos que pertenecen a lo que Ilamamos elipse. Para lo que vamos a explicar estas diferencias no son relevantes.

13 The difference between an oval and an ellipse of the same ratio may be less than the deformation of the dome. As a result, it is possible to argue about whether the base of a dome is oval or elliptical. The name issue is also difficult: even if the designer doesn't know what an ellipse is, a curve obtained by joining points belonging to what we call ellipse can be used deliberately, that is, controlling the consequences of his choice. These differences are not relevant to our discussion. para adaptarse a ella, estirándose en una dirección. Lo que eran circunferencias se convertirán en óvalos o elipses (la diferencia entre ellos puede ser pequeña). ${ }^{13} \mathrm{La}$ semiesfera se transformaría en una especie de medio melón, algo parecido a lo ahora Ilamaríamos elipsoide. Bóvedas de ese tipo son las de la sacristía de la catedral de Sevilla (Figura 7), del crucero de la catedral de Córdoba, y de la capilla de la Natividad de la catedral de Burgos, por ejemplo, todas del siglo XVI. La de Córdoba es de ladrillo y yeso, pero la de Sevilla es de sillería, y presenta un despiece que es también transformación del despiece por paralelos y meridianos que hemos explicado para la bóveda de media naranja.

En la bóveda de media naranja convencional todas las dovelas de la misma hilada eran iguales. Si hemos de emplear plantillas para su correspondiente sobre planta oval, las plantillas serán diferentes y solo se repetirán por simetría. No es el único inconveniente.

El lecho troncocónico en esta segunda ya no es de revolución. Su inclinación es continuamente variable. Las esquinas de la cara de intradós, y los ángulos que con ella forman lechos y juntas ya no son ortogonales. La pérdida de la ortogonalidad es también poco deseable -aunque ningún tratado lo explicita en ese momento-, pues da lugar a ángulos agudos, susceptibles de rotura o desportillamiento en el momento de la labra y colocación o más tarde. A pesar de eso, un trazado así se encuentra en el libro de Vandelvira, y, como hemos señalado, realizado en Sevilla y otros lugares. become ovals or ellipses (the difference between them can be very small). ${ }^{13}$ The hemisphere would be transformed in a kind of half melon, resembling what we now call ellipsoid. Domes of this type are, for instance, those of the Chapter House in Seville Cathedral (Figure 7), the transept of Cordoba cathedral and the Chapel of the Nativity of the Cathedral of Burgos, all of them from the 16th century. The vault of Cordoba is made of brick and plaster, but Seville's is made of carved stone masonry, and it shows an arrangement derived from the one by parallels and meridians as explained before for the hemispherical dome.

Voussoirs at the same course in the conventional hemispherical dome are equal. When adapting this system to the oval plan, the templates will be different, and will only be repeated by symmetry. This is not the only problem.

Conical beds will not follow the directrix of revolution cones, as their inclination will be continuously variable. Analyzing each voussoir, corners of the intrados face and angles between adjacent faces will not be orthogonal anymore. Although no text talks about this topic up to this moment, acute angles can be easily broken in the process of carving and placing or later on. Despite all these problems, we can find a tracing of this type in Vandelvira's book, and, as we have said before, there are built examples in Seville and elsewhere.

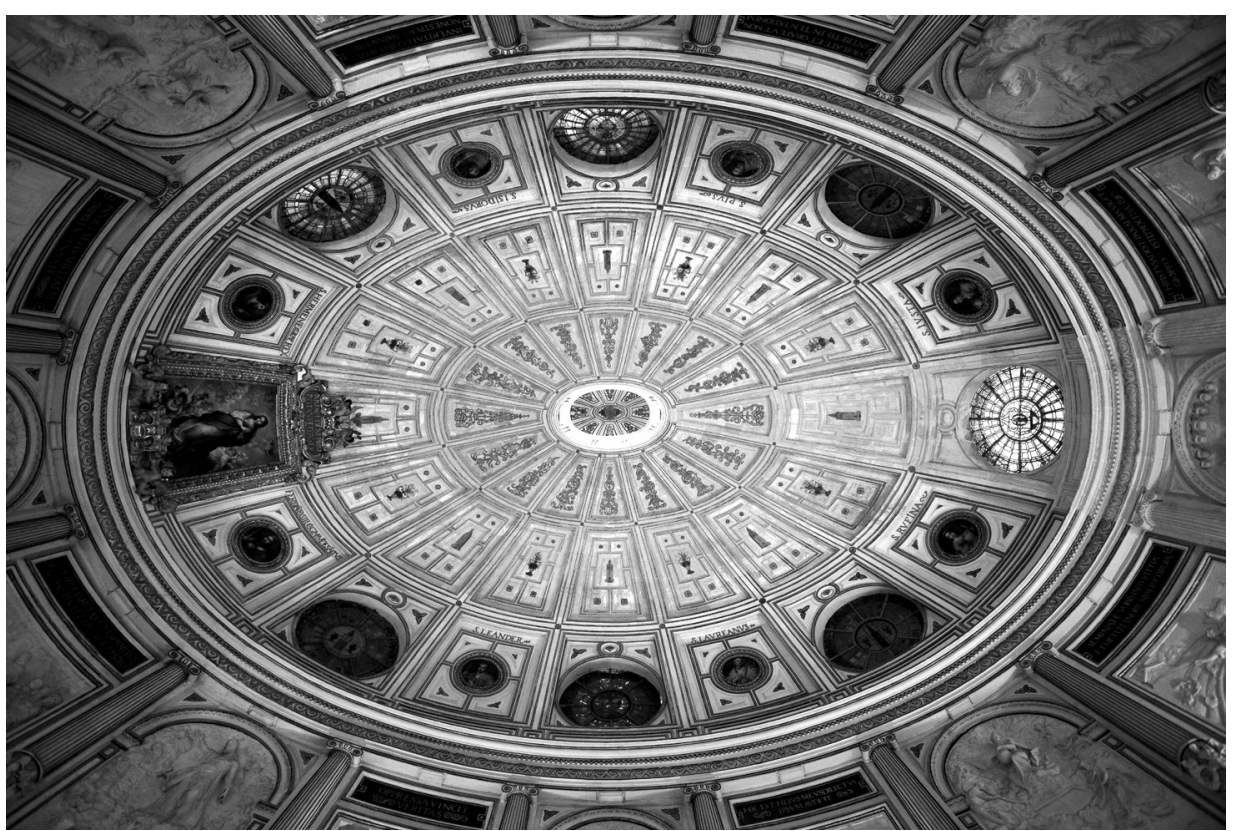




\section{LÍNEAS DE CURVATURA}

Consultando un tratado del siglo XVIII como es el de Frézier, comprobaremos que se intentó paliar estos problemas de la bóveda sobre planta oval o elíptica con diversos recursos. Sin embargo, la solución definitiva fue casi casual, consecuencia de las investigaciones geométricas de Gaspard Monge (18 y 19). Monge había descubierto lo que Ilamó "líneas de curvatura", dos familias de líneas sobre superficies algebraicas que en cada punto siguen la dirección de la máxima y mínima curvatura. Lo notable de estas líneas es que se cortan perpendicularmente, y que la recta normal, cuando pasa por una de ellas, genera una superficie reglada desarrollable.

Monge propuso la aplicación de las líneas de curvatura al despiece de las bóvedas elípticas. Para subrayar lo ventajoso de esta disposición, estableció que un correcto despiece de estereotomía debía de cumplir dos condiciones, la ortogonalidad de las facetas de las caras, y que la talla de éstas sea fácilmente comprobable, por ejemplo, con una regla; si la cara es, efectivamente, reglada, además sería deseable que se pudiera comprobar su contorno con una plantilla flexible, es decir, que fuera desarrollable.

El despiece de Monge para las bóvedas elípticas cumple esas condiciones, pero a cambio es extraordinariamente complejo (Figura 8). No sólo sigue presentando piezas diferentes, sino que las juntas (líneas de curvatura) son alabeadas y muy difíciles de trazar en una montea. Como consecuencia se da una curiosa paradoja: este despiece, debido a la importante influencia de Monge y su geometría descriptiva en la enseñanza técnica europea, ${ }^{14}$ aparece en la mayor parte de los tratados de estereotomía del siglo XIX, y, sin embargo, no conocemos ninguna realización. Es un modelo teórico.

Hay alternativas al despiece convencional y el de Monge. Una muy usual es admitir que los paralelos sean ovales y aprovechar el hecho de que pueden ser realmente paralelos, es decir, manteniendo siempre la distancia entre ellos (esto no es posible con elipses, pues la línea paralela a una elipse no es una elipse). De esa manera la bóveda puede estar formada por superficies de revolución y sus piezas cumplir la condición de ortogonalidad. También es posible disponer las hiladas verticales, que giren alrededor del eje horizontal mayor; eso conduce a hacer secciones transversales circulares, pero eso ocurre en la mayoría de las bóvedas ovales. Y de hecho esta es la solución, trivial, que alcanzaría el método

\section{CURVATURE LINES}

The 18th century treatise written by Frézier tried to overcome these disadvantages using different solutions, but the final one came almost casually after the geometrical researches by Gaspard Monge (18 and 19). Monge had discovered what he called "curvature lines", two families of lines over an algebraic surface following at each point the directions of maximum and minimum curvature. The most outstanding feature on these lines is that they intersect themselves forming a right angle. They also have another interesting property: the normal line to the surface along one of them generates a developable ruled surface.

Monge proposed applying curvature lines for cutting an oval dome. To emphasize the advantages of this configuration he set two conditions to be fulfilled by all correct stereotomy arrangements: faces should be orthogonal to each other and their carving easy to be checked, for example with a ruler. If the face follows the directrix of a ruled surface it would be desirable to be able to check its boundaries using a flexible template, in other words, that it were developable.

The quartering of Monge's elliptical vaults complies with those conditions, but it is extraordinarily complex (Figure 8). Not only pieces are again different, but joints (curvature lines) are warped and difficult to be traced. As a consequence a paradox arises: due to the large influence of Monge's Descriptive Geometry in European technical education, this layout appears in most of the 19th century stereotomy treatises, but as far as we know it was never built. It is a theoretical model. ${ }^{14}$

There are other alternatives to solve the problem of oval or elliptical vaults. A very usual one is to admit that parallels are ovals (not ellipses), as it is possible to draw parallel ovals but not parallel ellipses, so the distance between joints can be kept. A dome like that would be formed by multiple revolution surfaces, and its parts would fulfill the orthogonality condition between faces. It is also possible to arrange vertical rows revolving around the longer horizontal axis, so that cross sections are circular. In fact, this is the solution, which is trivial, obtained by the lines of curvature method if the ellipsoid had two equal axes.

One of Monge`s successors at the École Polytechnique which he founded, the engineer Jules de la Gournerie (1814-1883), criticized many of the proposals and ideas
14 Excepto Inglaterra, que mantuvo un acercamiento no sistemático al dibujo técnico.

${ }^{14}$ Except for England, where a nonsystematical approach to technical drawing was maintained. 
8. La propuesta de Monge para la bóveda elíptica, en el Traité de géométrie descriptive de J.-N.-Pierre Hachette (1822)

8. Monge's proposal for the elliptical vault in the Traité de géométrie descriptive by J.-N.-Pierre Hachette (1822).

\footnotetext{
${ }^{15}$ Quien por cierto detestaba las superficies "irregulares", anticipando así la preferencia por lo geométrico y abstracto (9).

15 Frézier hated "irregular" surfaces, advancing the preference for geo-
} metrical and abstract forms (9). de las líneas de curvatura si fuera aplicado a un elipsoide con dos ejes iguales.

Uno de los sucesores de Monge en la École Polytechnique por él fundada, el ingeniero Jules de la Gournerie (1814-1883), criticó muchas de las propuestas e ideas de su antecesor, y se empeñó especialmente en demostrar que las condiciones enunciadas para un despiece correcto no debían ser tomadas muy literalmente. La Gournerie era un geómetra notable y un teórico riguroso, pero, al contrario que Monge, pensaba que la estereotomía debía aprender de la tradición, aprender del oficio, y tener en cuenta la realidad, especialmente circunstancias mecánicas que Monge había despreciado (22). En esto último no es del todo justo, pues los tratados de cortes de piedras han aludido pocas veces a la estabilidad, y cuando lo han hecho ha sido en secciones del texto separadas del despiece o la geometría-Martínez de Aranda, cuando ofrece la Ilamada regla del tercio (23, pp.46-47) o Frézier (9, II pp.87-105)-.

Otra vez aparece Euclides en esta disputa. La Gournerie recuerda un propósito que se había hecho Philibert De l'Orme. De I'Orme encuentra engorrosa y poco útil la teoría de Euclides, y anuncia (24, p.124): "Emplearé el tiempo adecuado en revisar a Euclides y acomodar su teoría a la práctica arquitectónica, añadiendo a Vitruvio y organizándolo según un cierto método." A continuación afirma que la primera tarea, la explicación geométrica de los procedimientos (representada por la mención a Euclides), ya se cumplió suficientemente en el siglo XVIII con el tratado de Frézier, ${ }^{15}$ y la segunda estaba por hacer, pues "Monge se alejó del objetivo, porque dejó de lado a Vitruvio", donde debemos de entender que "Vitruvio" representa el arte de la construcción.

Antes he mencionado la capilla de la $\mathrm{Na}$ tividad en la catedral de Burgos. Un estudio pormenorizado ha revelado que las líneas de junta que aparentan seguir los paralelos de la superficie son en realidad alabeadas (25). En este caso no se trata del alabeo propio de las líneas de curvatura de Monge. Hemos podido comprobar que estas líneas son en cada caso el resultado de la intersección de un cono de revolución con la superficie de la esfera. Es decir, que la complicación aquí tuvo una importante consecuencia práctica: los lechos entre hiladas presentan siempre la misma inclinación (Figura 9). Por otra parte, el vértice de estos conos no está siempre en el centro de la base, sino más arriba, y así se consigue no incrementar esa inclinación, y probablemente ahorrar o suprimir las cimbras. Es ra- of his predecessor. He insisted especially on showing that the conditions set for a right arrangement should not be literally taken. La Gournerie was an outstanding geometer and rigorous theorist, but, unlike Monge, he thought that stereotomy should learn from tradition and crafts, and should take into account reality, especially mechanical circumstances set aside by Monge (22). In the latter, La Gournerie was not entirely fair, as stonecutting treatises do not usually tackle stability problems, and if they do, it is in separate sections apart from stone cuts or geometry-for instance Martínez de Aranda, when he proposes a rule to dimension buttresses, (23, pp.46-47) or Frézier (9, II pp.87-105)-.

Euclid appears again in this dispute. La Gournerie wrote that Philibert de l'Orme had proposed (24, p.124): "I will use adequate time to review Euclid's work as to accommodate his theory to the practice of architecture, including Vitruvius and organizing it according to a certain method." De l'Orme said that because he thought that Euclid's theory was cumbersome and unhelpful. La Gournerie asserts then that the first task, the geometrical explanation of procedures (represented by the mention of Euclid), was already sufficiently fulfilled in the 18th century by Frézier's book, ${ }^{15}$ and that the second task was yet to come, because "Monge had moved away from the target because he set Vitruvius aside". Where it says "Vitruvius" we must understand that this refers to the art of construction.

I mentioned before the chapel of the Nativity in the Cathedral of Burgos. A detailed study has revealed that the joint lines, which apparently follow surface parallels, are actually warped (25). But it is

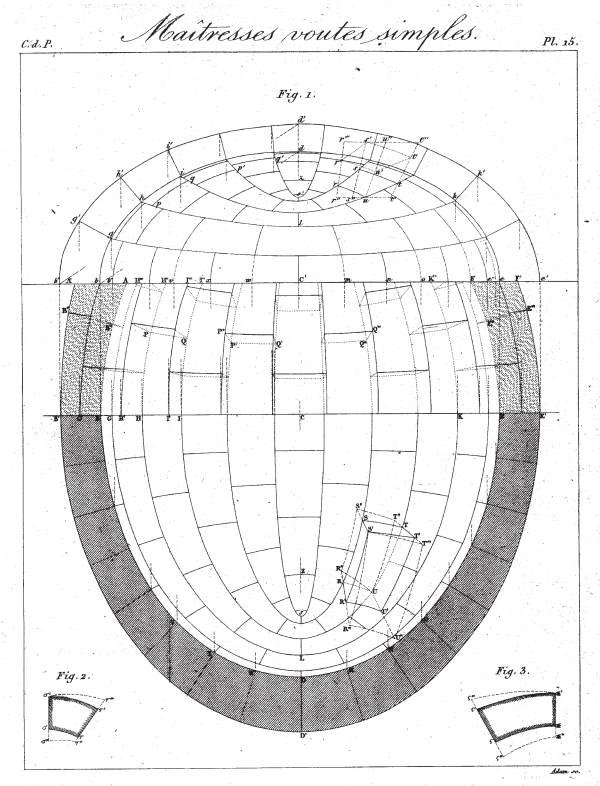

8 
zonable pensar que se labraron in situ, con la ayuda de un cintrel.

\section{EL CONTROL POR LA LÍNEA}

En este último caso, y en algunas bóvedas vaídas también analizadas, ${ }^{16}$ es evidente que el control y el diseño de las superficies dependen del establecimiento de ciertas líneas.

Muchas bóvedas que aparentan ser esféricas, en realidad son el resultado de la traslación de un arco de circunferencia. En el caso de las bóvedas tabicadas esto es habitual. ${ }^{17}$

La concepción del volumen en la mente del artista es un mito (17). En el caso de la arquitectura, líneas directrices, secciones y perfiles guían la concepción y la construcción. El control de un conjunto de líneas no es, pues, una estrategia exclusivamente gótica, sino una manera ineludible de abordar la construcción de una superficie (21). Esto pone en duda la prioridad de las concepciones geométricas en el diseño de las bóvedas. Simplificando, decimos que una bóveda vaída es esférica, o que una bóveda de arista es intersección de dos cilindros (tema que en este mismo número se estudia), pero la cantidad de excepciones es abrumadora, y conducen siempre a pensar la bóveda como resultado de un modo material de hacer, apoyado en un control de elementos lineales.

En la historia de la técnica no es extraño que la explicación llegue después de la resolución práctica. ${ }^{18}$ En el caso de los cortes de piedra, lo que llegó después fue una justificación teórica, capaz de resolver problemas teóricos, pero no de mejorar la realidad del trabajo constructivo. Veamos otro ejemplo.

\section{CAPIALZADO DE MARSELLA}

El siglo XIX se propone resolver definitivamente viejos problemas, y en el caso del Ilamado Capialzado de Marsella lo hace empleando reflexiones geométricas muy interesantes (18, pp.307-309, y 19, pp.278286). Se trata de la cubrición de un hueco, puerta o ventana, que aparece como arco de medio punto en un paramento y como arco rebajado en el otro (Figura 10). En el arco de medio punto se encuentra la mocheta, que aloja la carpintería. La superficie del capialzado, que es reglada, está diseñada para que al abrir las hojas de la carpintería, rematadas por cuartos de circunferencia, no rocen al intradós y queden bien alojadas en los planos de derrame de las jambas. El intradós reglado está formado not the warping of Monge's curvature lines. We have been able to check that each of these lines is the result of the intersection of an inverted revolution cone with the surface of the oval intrados. So it is a complicated solution but offers significant advantages, as beds between rows have always the same inclination (Figure 9). Furthermore, the apex of these cones is not always placed in the center of the base but higher, which means that inclination does not increase, probably avoiding the use of a centering. These beds were likely carved with the help of a stick or tightrope.

\section{CONTROL BY THE LINE}

In the latter case, and in some other sail vaults also analyzed, ${ }^{16}$ it is evident that the control and design of the surfaces requires the establishment of certain lines.

Many apparently spherical domes are actually the result of the parallel translation of an arc. It usually happens in the so called tile vaults "a la catalana".17

We can say that the idea of the artist previously conceiving a volume and then translating it directly to material construction is actually a myth (17). Lines, sections and profiles guide conception and construction of architecture. Controlling a set of lines is not an exclusive Gothic strategy but the only way to tackle the construction of any kind of surface (21). We tend to think that conception of a surface as a whole is a priority issue. Therefore, we simplify the descriptions, saying that a dome is hemispherical, or a groin vault is the intersection of two cylinders, etc But the truth is that these domes are the result of a material way of doing, which is controlled by linear elements, and the result may be different from that imagined from those descriptions.

History of technology often shows explanations coming after practical solutions. ${ }^{18}$ In the case of stonecutting, problems were solved first and theoretical justification came next, able to solve theoretical problems but unable to improve the reality of constructive work. Here's another example.

\section{ARRIERE-VOUSSOIR DE MARSEILLE}

Stonecutting tracing tackles the final solution to old problems in the 19th century. The rear vault from Marseille allowed carrying on interesting geometrical reflections (18, pp.307-309, and 19, pp.278-286). This kind of arrangement is used to cover a door or window from an external round arch to
9. En una bóveda oval o elíptica: arriba, lecho cónico que mantiene su pendiente, abajo, lecho cónico apoyado en un paralelo de la superficie (generatrices de inclinación variable).

9. Oval or elliptical vault: above, conical bed with constant slope below, conical bed along a parallel (variable slope).
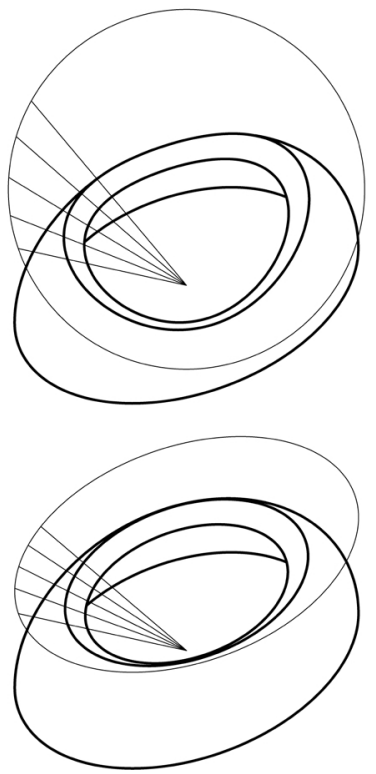

${ }^{16}$ Además de la mencionada en (16), también (20) y el estudio teórico (21).

${ }^{16}$ In addition to that mentioned in (16), also (20) and the theoretical study (21).

17 Si se traslada una semicircunferencia a lo largo de otra, la apariencia puede resultar algo apepinada, pero si se toman simplemente arcos escarzanos, es difícil distinguir el resultado de este procedimiento de la adopción de una bóveda realmente esférica. Un caso práctico reciente son las vaídas del aeropurto de Alicante.

7 If you move a semicircle throughout the other, the appearance may be too high, but if you take just segmental arches, it is difficult to distinguish the result from the adoption of a truly spherical dome. Vaults at Alicante's airport are a recent example.

${ }^{18}$ He escuchado al profesor José Manuel Sánchez Ron ilustrar esta opinión con el ejemplo de la máquina de vapor, anterior a la teoría de la termodinámica.

${ }^{18}$ I listened to Professor José Manue Sánchez Ron illustrate this view with the example of the steam engine, prior to the theory of thermodynamics. 
10. Capialzado de Marsella, en el Traité de la Coupe des Pierres, de Jean Baptiste de la Rue (1728).

10. Arriere-Voussoir de Marseille, in the Traité de la Coupe des Pierres, by Jean Baptiste de la Rue (1728).

11. Capialzado de Marsella, en la Estereotomía de la piedra de Antonio Rovira y Rabassa (1899).

11. Arriere-Voussoir de Marseille, in the Estereotomía de la piedra by Antonio Rovira y Rabassa (1899). en realidad por dos partes distintas -antes y después del rincón que produce el final del escarzano- las cuales, teóricamente, pueden no encontrarse en perfecta continuidad y tangencia. Hasta el siglo XIX nadie se había dado cuenta de que eso podía suceder. Pero advertir el problema permitió llenar páginas y páginas de los tratados de estereotomía con curiosas aplicaciones de la teoría de las superficies regladas (Figura 11).

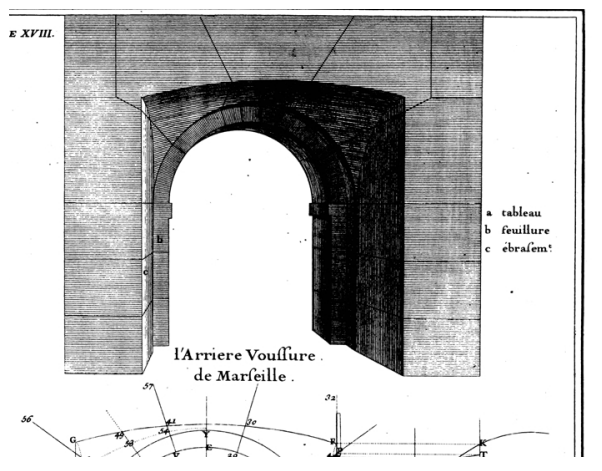

10

\section{CONCLUSIÓN}

Así pues, hemos visto que los recursos de la estereotomía nacieron en el seno de la propia actividad constructiva, en función de sus necesidades, y que las abstracciones geométricas resultantes y los procedimientos gráficos que hubo que desarrollar enriquecieron más tarde a la teoría geométrica. Hemos visto también como las bóvedas semiesféricas o vaídas son un lugar de experimentación. Su variante, la bóveda de una sola hilada helicoidal, es un juego sin justificación suficiente para la dificultad que entraña. Al adaptar la media naranja a una planta oval aparecieron curiosos problemas, y una propuesta para su resolución definitiva, extraordinariamente difundida, no pasó de la teoría. Ya en el siglo xIX, amplios conocimientos sobre las superficies regladas son aplicados a un viejo problema; pero, pero para eso fue necesario destacar que el problema existía, lo que hasta entonces había pasado inadvertido en la práctica.

Podríamos añadir que, también en el siglo XIX, se destacó el problema de la construcción de grandes arcos oblicuos, asunto al que se aplicó la estereotomía con todas sus armas durante décadas, poniendo a prueba la capacidad de la geometría de la época, ocupando también buena parte de los tratados de estereotomía, con algunas soluciones prácticas (elaboradas por in- an internal segmental arch, with carpentry placed under the first one (Figure 10). A ruled surface is designed so that the two sheets of the carpentry work can be opened without obstruction. This intrados surface is actually made up of two distinct parts which may not be in perfect continuity but until the 19th century this problem had not been noticed. Theory of ruled surfaces and descriptive geometry was then used to solve it filling many pages of stereotomy treatises (Figure 11).

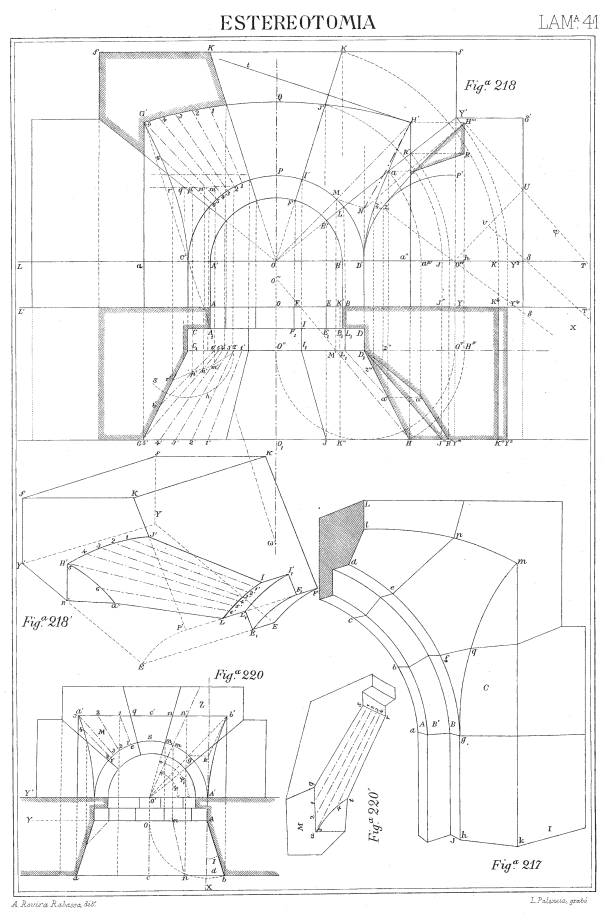

11

\section{CONCLUSION}

Thus, we have seen that stereotomic procedures were born within constructive activity itself, depending on the needs, and resulting geometrical abstractions and graphical methods enriched the science of geometry afterwards. We have also seen that hemispherical domes or sail vaults constituted a place for experimentation. The dome of a single helical row is a way to address the same problems, but there is no justification for its complexity. Dome on oval or elliptical plans led to other problems, and a proposal for its final solution, extremely widespread, proved to be only theoretical. In the 19th century the idea to apply the knowledge of ruled surfaces to an old problem thrived, but it was necessary to artificially emphasize that the problem existed.

The problem of building large oblique arches was also highlighted in the 19th 
gleses) y otras teóricamente perfectas pero enormemente complejas (elaboradas por franceses).

Emplear el término estereotomía fue la manera de dignificar con una expresión técnica la vieja traza de cantería. La estereotomía es un conjunto de soluciones alcanzadas con esfuerzo, empleando una cierta intuición del espacio. Y, si bien en algunos casos sería posible hablar de una experimentación útil al progreso del corte de piedras, el interés por el alarde unas veces, y la preocupación por la idealización geométrica otras, condujo en ocasiones a soluciones innecesariamente complicadas.

\section{AGRADECIMIENTOS}

Este trabajo ha sido realizado en el marco del Proyecto de Investigación "Construcción en piedra de cantería en los ámbitos mediterráneo y atlántico. Análisis de ejemplos construidos" (BIA2009-14350) del Plan Nacional de I+D+i, financiado por el Ministerio de Ciencia e Innovación. century and Stereotomy was applied there with all its resources. A practical solution (prepared by English people) and a less practical but theoretically perfect (developed by French people) were given.

The term stereotomy was employed to dignify ancient activity. Stereotomy is a set of solutions achieved with effort, using a certain intuition of space. In some cases it would be possible to speak of experimentation useful for the progress of stone construction. However, the wish to show off and also the concern about finding other geometrically perfect solutions, sometimes led to unnecessarily complicated solutions.

\section{ACKNOWLEDGEMENTS}

This work has been carried out under the Research Project "Construcción en piedra de cantería en los ámbitos mediterráneo y atlántico. Análisis de ejemplos construidos" (BIA2009-14350) funded by the Ministry of Science and Innovation.

\section{REFERENCIAS / REFERENCES}

(1) Sakarovitch, J. (2009). From the Stone Carver's Techniques To Descriptive Geometry. En El arte de la piedra: Teoría y práctica de la Cantería. Madrid: CEU Ediciones. 7-26.

(2) Rabasa Díaz, E. (2007)."Principios y construcción de las bóvedas de crucería". Loggia, 20, 86-97.

(3) Palacios Gonzalo, J. C. (2009). La cantería medieval. La construcción de la bóveda gótica española. Madrid: Munilla-Llería.

(4) Willis, R. (1842). On the construction of the vaults of the Middle Ages. Transactions of the RIBA, vol 1, 1-69.

(5) Calvo López, J., et al. (2013). The Tracing for the Sail Vault at the Murcia Cathedral Vestry: Surveying a 16th-Century Full-Scale Working Drawing. International Journal of Architectural Heritage: Conservation, Analysis, and Restoration, 7:3, 275-302.

(6) Lotz, W. (1985). La representación del espacio interior en los dibujos de arquitectura del Renacimiento italiano. En La arquitectura del Renacimiento en Italia: Estudios. Madrid: Hermann Blume, 1-64.

(7) Schopenhauer, A. (2009 [1819]). El mundo como voluntad y representación. Madrid: Trotta.

(8) Pinto Puerto, F. (2001). Las esferas de piedra: Sevilla como lugar de encuentro entre arte y ciencia en el Renacimiento. Sevilla: Diputación.

(9) Frézier, A.-F. (1980 [1737-39]). La théorie el la practique de coupe des pierres el de bois... ou traité de stéréotomie... Nogent-le-Roi: Jacques Laget.

(10) Perdiguier, A. (1977 [1854]). Mèmoires d'un compagnon. París: François Maspero, p.10.

(11) Calvo López, J. (2011). From Mediaeval Stonecutting to Projective Geometry. Nexus Network Journal 13 (2011) 503-533.

(12) Pérouse de Montclos, J. M. (1982). L'Architecture à la française. París: Picard.

(13) Ruiz de la Rosa, J. A. (2006). Dibujos de ejecución. Valor documental y vía de conocimientos de la catedral de Sevilla. En La catedral gótica de Sevilla: Fundación y fábrica de la obra nueva. Sevilla: Universidad de Sevilla, 297-347.

(14) Taín Guzmán, M. y P. Natividad Vivó (2011). La montea para las bóvedas de horno de Santa Columba de Carnota. En S. Huerta, I. Gil Crespo, S. García y M. Taín (eds.), Actas del Séptimo Congreso Nacional de Historia de la Construcción. Madrid: Instituto Juan de Herrera, SEHC, II, 1389-1399. 
(15) Palacios Gonzalo, J. C. (1990). Trazas y cortes de cantería en el Renacimiento español. Madrid: Ministerio de Cultura.

(16) López Mozo, A. (2004). Traza y construcción en la bóveda vaída de la cocina del convento del Monasterio de El Escorial. En Dibujar lo que no vemos. Actas del X Congreso Internacional de Expresión Gráfica Arquitectónica. Granada: Universidad de Granada, 1.021-1.031.

(17) López Mozo, A., E. Rabasa Díaz y M. Sobrino González (2011). "La línea en el control material de la forma". En S. Huerta, I. Gil Crespo, S. García y M. Taín (eds.), Actas del Séptimo Congreso Nacional de Historia de la Construcción. Madrid: Instituto Juan de Herrera, SEHC, I, 743-754.

(18) Sakarovitch, J. (1998). Epures d'architecture: De la coupe des pierres a la géométrie descriptive. Basel, Boston, Berlin: Birkhäuser.

(19) Rabasa Díaz, E. (2000). Forma y construcción en piedra: de la cantería medieval a la estereotomía del sigl xIx. Madrid: Akal.

(20) Alonso Rodríguez, M. Á. y J. Calvo López (2011). Bóvedas vaídas en el ámbito casteIlano. La iglesia de Navamorcuende (Toledo). En S. Huerta, I. Gil Crespo, S. García y M. Taín (eds.), Actas del Séptimo Congreso Nacional de Historia de la Construcción, Madrid: Instituto Juan de Herrera, SEHC. I, 65-74.

(21) Senent Domínguez, R. (2011). "Las bóvedas irregulares del tratado de Vandelvira. Estrategias góticas en cantería renacentista". En S. Huerta, I. Gil Crespo, S. García y M. Taín (eds.), Actas del Séptimo Congreso Nacional de Historia de la Construcción, Madrid: Instituto Juan de Herrera, SEHC. II, 1329-1338.

(22) Rabasa Díaz, E. (2011). La Gournerie versus Monge. Nexus Network Journal 13 (3), 716-735.

(23) Martínez de Aranda, G. (1986 a.1600]). Cerramientos y trazas de montea. Madrid: Servicio Histórico Militar / CEHOPU.

(24) La Gournerie, J. M. de (1874). Mémoire sur l'enseignement des arts graphiques. Journal des Mathématiques pures et appliqués, XIX: 113-156.

(25) Alonso Rodríguez, M. A., et al. (2009). Functionalism and caprice in stonecutting. The case of the Nativity Chapel in Burgos Cathedral. En Proceedings of The Third International Congress on Construction History. Cottbus: Brandenburgische Technische Universität, Faculty of Architecture, Civil Engineering and Urban Planning. 31-38. 